\title{
Why Pure Vegetarianism is Not All that Great an Idea for India. An Important Study for Pune District Perspective Tops Self-Reported Private Co- Educational Pharmaceutical Institutions in Number of Abandoned Children
}

\section{Rahul Hajare*}

Fellow Indian Council of Medical Research, India

*Corresponding Author: Rahul Hajare, Fellow Indian Council of Medical Research, India.

Received: August 29, 2019; Published: September 13, 2019

DOI: 10.31080/ASNE.2019.02.0108

\begin{abstract}
Human has two more undocumented blood cells seen. 'The real reason is early marriage, which is prevalent in many parts of Pune district. These girls are married off at 23 and by the age of 274 they have three children. By the age of 30 they are separated and the children are abandoned.
\end{abstract}

Keywords: Children; Pune; India

\section{Introduction}

A recent report by the ministry of women and child development painted an unflattering image of across Maharashtra when it revealed that the largest number of abandoned children were from the state.The report, compiled by the Childline India Foundation and the National Commission for Protection of Child Rights, revealed that Maharashtra 1,550 abandoned children in the age group of 7 to 18, followed by West Maharatra (933 children) and East Maharashtra (729). Sexual exploitation is also routine and in government-run shelter homes they try to ensure news of it does not leak out [1]. It is the restrictions placed on a girl child. Parents are very protective and don't give the girl any freedom. This makes young girls rebel. "Do you think the cradle baby scheme (where you can leave your new born baby and nobody questions you) is the reason for Maharashtra having the highest number of abandoned children in the country? The cradle baby scheme was popular when it started. Now it has very few babies coming in [2]. The real reason is early marriage, which is prevalent in many parts of Maharashtra. These girls are married off at 23 and by the age of 27 they have three children. By the age of 30 they are separat- ed and the children are abandoned. Only grandparents look after these children if they are there. Many girls do not finish their $12^{\text {th }}$ standard. There is no vocational training in school and safety is long way. Elopement has increased. Pune district has a home for these girls because it is rampant there. There is no sex education in schools and so they are not aware of preventive measures [3].

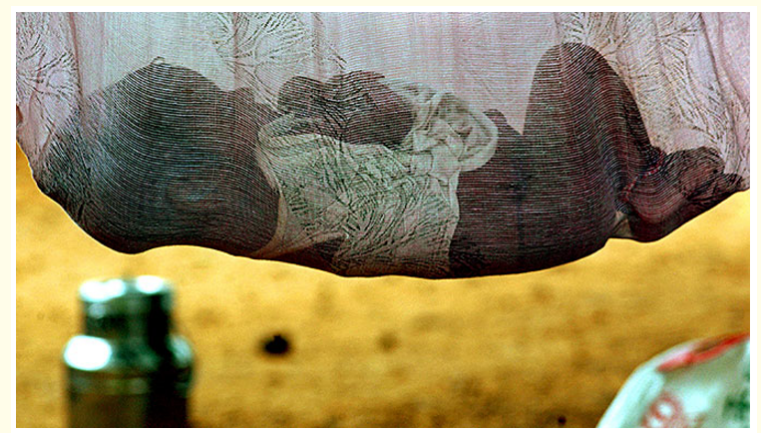

Figure 1: A homeless child sleeps in a makeshift hammock on Swargate Bus Stand in Pune, Maharashtra State. 
Why Pure Vegetarianism is Not All that Great an Idea for India. An Important Study for Pune District Perspective Tops Self-Reported Private Co- Educational Pharmaceutical Institutions in Number of Abandoned Children

How come there are so many single mothers even though their partner can be jailed for rape and different women then there is other danger. I have already told you that early marriage and elopement are the reasons for this. Another reason is the restrictions placed on a girl child. Parents are very protective and don't give the girl any freedom. This makes young girls rebel. I have many a time explained to the government that keeping the children with the parents is the least expensive way of looking after them [4]. The cost in shelter homes is much higher. When parents send their children to shelter homes the government should pay the parents to keep their children with a probation officer keeping a regular eye on the family. But is not sex education part of the curriculum. No, but it should be and also compulsory. What are the conditions like for these children in the shelter homes. The conditions are not desirable in the government shelter homes and also those funded by the government and run by NGOs. Corporal punishment is rampant and so is malnutrition. Sexual exploitation is regular and in the government homes they make sure it does not leak out. Is there any data as to how many of these unwed mothers are from shelter homes [5]. No. But there are shelter homes for these pregnant girls. Is poverty the main cause why children are abandoned. Poverty is one of the reasons and the other is social stigma. A single mother is looked down upon. Her character is suspect. Another reason is there is nobody to care for and protect these girls. We had gone on a survey in Pune outgoing area and we found that girls were most vulnerable on the way to school. The roads leading to the school were totally isolated [6]. So what the parents do is stop sending them to school. The government builds schools, but never bothers to find out if the school is accessible through safe roads. As a child protection specialist what steps would you advise to prevent children for being abandoned. The steps have been clearly put up by UNICEF and we need to follow them, we have to teach the child decision making and also problem solving skills. We have to teach them how to gather Information [7]. We have to teach them how to evaluate future consequences of present actions. We have to tell them that there are more ways than one to tackle a particular issue. We have to teach them about attitude and values and also how these factors motivate us. We have to show them how to read others by their actions. They have to analyse attitudes, values, social norms and beliefs. They have to learn self-control, self-esteem and self-confidence and also how to build these three. They have to be taught self-awareness skills including awareness of rights, influences, values, attitudes, strengths and weaknesses [8]. They have to be taught to set goals and also how to achieve it. At every step in their quest they must know how to self-evaluate/self-assess and also monitor their every step.

It is very important to teach them anger management and how to deal with grief and anxiety [9].

\section{Conclusion}

Another reason is the restrictions placed on a girl child. Parents are very protective and do not give the girl any freedom. This makes young girls rebel.

\section{Recommendation}

Government should earn Loyalty is an important trait has limits.

\section{Bibliography}

1. Rahul Hajare. "Tuberculosis at the socialized principal Pharmaceutical Institutions in India without comorbidity in different age groups: An Attractive Findings". APTI WOMEN'S FORUM (2019): 12-13.

2. Hajare R. "Rotational symmetry and corresponding angle of some natural sex restore the appearance of face". MOJ Drug Design Development \& Therapy 2.5 (2018): 210-212.

3. Rahul Hajare. "India's adultery law is 'staggeringly sexist' towards women (evaluation without power politics culture in private pharmacy Institutions in India)". Pharmaceutical Sciences \& Analytical Research Journal 1.3 (2018): 180011.

4. Rahul H. "Shocking Link of Rapid Rise in Pre-Cancer among the Healthy Adults in Pharmaceutical Institution Pune University India Living with Low Oxygen and Poor Sanitation Environment: Affordable Treatment Rate Three-Times Over". Global Journal of Addiction \& Rehabilitation Medicine 5.5 (2018): 555673.

5. Rahul H. "Relationship between emotional intelligence and variation of high risky behavior in private pharmacy institutional principal and assistant professor combined attending from long distance driver role in pune university, India: An Attractive Findings". JOJ Sciences 1.4 (2018): 555567. 
6. Rahul Hajare. "Facial Recognition Technology and Detection of Over Sexuality in Private Organizations Combined with Shelter House. Baseline Integrated Behaviouraland Biological Assessment among Most at-Risk Low Standards Hope Less Institutions in Pune, India". Advanced Research in Gastroenterology \& Hepatology 11.4 (2018): 555816.

7. Rahul Hajare. "Sensitivity and Specificity of the Nobel Prize Testing to the Dogs". (2018).

8. Rahul Hajare. "My Wife has Murdered Undocumented Immigrant”. (2018).

9. Rahul Hajare. "Evaluation of Indian Deprived Female Sex Perspective Tests about Pelvis Decline Self-Reported NonGovernmental by Pass Pharmaceutical Instituions in India: February 2019".

Volume 2 Issue 10 October 2019

(C) All rights are reserved by Rahul Hajare. 